\title{
The genetic diversity of ayam ketawa (Gallus gallus domesticus, Linneaus, 1758) in Bangkalan District, Madura Island, Indonesia
}

\author{
ABINAWANTO", TRI ZULISTIANA, RETNO LESTARI, ASTARI DWIRANTI, ANOM BOWOLAKSONO \\ Department of Biology, Faculty of Mathematics and Natural Sciences, Universitas Indonesia. Jl. Prof. Soedjono D. Poesponegoro (Lingkar Kampus \\ Raya), Pondok Cina, Beji, Depok 16424, West Java, Indonesia. Tel./fax.: +62-21-7270163, "email: abinawanto.ms@ sci.ui.ac.id
}

Manuscript received: 20 September 2020. Revision accepted: 11 May 2021.

\begin{abstract}
Abinawanto, Zulistiana T, Lestari R, Dwiranti A, Bowolaksono A. 2021. The genetic diversity of ayam ketawa (Gallus gallus domesticus, Linneaus, 1758) in Bangkalan District, Madura Island, Indonesia. Biodiversitas 22: 3145-3155. Ayam Ketawa, a variation of Gallus gallus domesticus Gallus gallus domesticus, comes from Sidendreng-Rappang (Sidrap) District, South Sulawesi, Indonesia. Apart from Sidrap, ayam ketawa farms are also found in Bangkalan District, on the island of Madura, Indonesia. Ayam ketawa from Bangkalan District often wins national level contests. Therefore, the research was carried out with the aim of knowing the genetic diversity of ayam ketawa in Kamal Subdistrict, Socah Subdistrict, and Burneh Subdistrict, based on bioacoustic, morphometric, and barcoding DNA analysis. The studied ayam ketawa consists of dangdut and slow types. The longest duration (6.00 \pm 3.0$)$ seconds was shown by ayam ketawa from Kamal Subdistrict, while the highest number of syllables $(7.20 \pm 5.80)$ came from Socah Subdistrict. The results of the Mann-Whitney test showed that eight morphological characters were significantly different $(\mathrm{P}<0.05)$ between ayam ketawa population in Kamal and Burneh subdistricts, namely body weight, femur length, shank length, shank circumference, wing length, comb height, third finger length, and breastbone length. Four morphological characters differed significantly $(\mathrm{P}<0.05)$ between ayam ketawa population in Kamal and Socah subdistricts, namely shank length, wing length, third finger length, and sternum length. Three morphological characters were significantly different $(\mathrm{P}<0.05)$ between the Burneh and Socah subdistricts population, namely body weight, femur length, and shank circumference. The analysis results of DNA Barcoding gene of the Cytochrome Oxidase subunit 1 (CO1) showed a genetic distance ranging from 0.025 to 1.872 .
\end{abstract}

Keywords: Ayam ketawa, Bangkalan, Cytochrome Oxidase subunit 1, Gallus gallus domesticus

\section{INTRODUCTION}

Chicken is an important commodity for Indonesian society. Indonesian people raise chicken to fulfill economic needs, as a source of protein, and as a hobby (Maryono 2012). The potential of chicken being reared as a pleasure (hobby) can be useful as a stress reliever. Several livestock owner groups raise chickens to enjoy the beauty of their feathers, body shape, and the sweetness of their voice. Rukmana (2003) reported that more than 31 varieties of chicken have spread throughout Indonesia and have distinctive morphological characteristics based on their region of origin. For example, in South Sulawesi, there is variety of chickens with distinctive rooster sound characteristics, namely ayam ketawa (Junaedi 2012; Bugiwati and Ashari 2013; Effendi and Abinawanto 2015).

Ayam ketawa, known as manu gaga, is a variety of native chicken (Gallus gallus domesticus) originating from Sidenreng Rappang (Sidrap) District, South Sulawesi, Indonesia (Junaedi 2012; Bugiwati and Ashari 2013; Effendi and Abinawanto 2015). The ayam ketawa is included in singing chicken, which has a distinctive crow resembling a laughing person. Ayam ketawa can crow longer than other native chickens (Junaedi 2012). The uniqueness of the crow of the ayam ketawa makes it the prima donna for chicken hobbyists, so more and more ayam ketawa hobbyists choose to take care of it, indirectly spreading ayam ketawa wider.
At first, the distribution of the ayam ketawa was quite limited. In the 1940s, the ayam ketawa was kept and bred only in the Bugis aristocracy, as a symbol of social status (Maryono 2012). Until the end of the 2000s, the rooster population in Sidrap District decreased, due to a change in trend or a penchant for the Bugis aristocrats. The ayam ketawa began to spread to communities outside Sidrap District, and, finally, outside the island.

The spread of the ayam ketawa outside of Sidrap was caused by the human. Lack of attention to ayam ketawa (due to a shift in trend) has led some people who like ayam ketawa to breed them outside their original home areas. In addition, the increasing number of singing chicken contests outside Sidrap and the difficulty of buying and selling and transporting animals between regions, have caused many ayam ketawa hobbyists outside Sidrap to raise ayam ketawa individually or in groups. Until now, there are many people in several areas in Indonesia that have developed ayam ketawa farms, such as Sidrap, Kendari, Jakarta, Bogor, Yogyakarta, and Bangkalan.

Bugiwati and Ashari (2013), and Effendi and Abinawanto (2015) reported that differences in the environment for raising ayam ketawa led to differences in characters, such as bioacoustic, morphometric, and DNA barcoding. Bioacoustic is a study that learns the character of sound, voice function, sound anatomy and physiology, sound analysis, and sound in communicating process in animals, such as their behavior in communication. 
Bioacoustic analysis can be used to estimate the population, identification, behavior of animals, and the impact of human-made sounds on them (Klinck and Mellinger 2010).

Bugiwati and Ashari (2013) conducted research on the bioacoustic of ayam ketawa in Sidrap which showed that the ayam ketawa in Sidrap was divided into two types: the slow type and the dangdut type. The slow type has a longer crowing duration compared to the dangdut type. In addition, Effendi and Abinawanto (2015) also reported that the slow ayam ketawa in the Jakarta population tends to have a longer crowing duration than the dangdut type.

Morphometrics can be defined as a method by which morphological characters are described through measurement, calculation, or scoring (Bookstein 1982). Morphometric analysis is used to determine the diversity and relationship of a species through testing of morphological characters in general (Hutt 1949). Overall morphological characters are transformed as quantitative, measurable parameters that are numerical, so it requires multivariable analysis to produce useful results as information on diversity (Hillis 2003).

Research on body character reported by Rachma et al. (2013) stated that the ayam ketawa in Sidrap District did not show any differences in body size characters from native chickens (non-ayam ketawa). Andrianto et al. (2015) reported that the body size of the rooster in Kendari had the highest coefficient of diversity (CD) on neck length $(11.47 \%)$, third finger length $(11.10 \%)$, chest length $(10.68 \%)$, and circumference of claws $(10.16 \%)$, while the lowest coefficient of variability was chest circumference $(4.01 \%)$ and back length $(4.01 \%)$.

DNA barcoding is an organism identification technique using certain gene pieces that have proven their ability to distinguish individuals at one species level (Zein and Prawiradilaga 2013). Gao et al. (2011) reported that barcoding DNA testing using Cytochrome c oxidase subunit-1 (COI) could be applied to chickens. The COI gene was chosen as the gene whose sequence is used in the barcode because it meets the criteria in determining the identity of almost all vertebrate animals. According to Zein and Prawiradilaga (2013), the advantage of the COI gene character is that it is relatively short, which is around 500$700 \mathrm{bp}$ (base pair), and it has low variability, which is around $1-2 \%$, so it can identify the identity of even very closely related species. In addition, the COI mitochondrial gene has a large copy number, so the amplification results will be maximized. DNA barcoding research on ayam ketawa has just been carried out in Jakarta and Sidrap District (Bullo, Macege, Kanare, Rappang, Sidreng Farms) which show that the ayam ketawa originating from the Bullo farm have the closest genetic distance to the ayam ketawa on the farm in Sidreng (Effendi 2017). Bangkalan District in Madura Island has a domesticated ayam ketawa from Sidrap District brought by Buginese migrants. In 2017, in Bangkalan District, the number of ayam ketawa was estimated at 300 or nearly a third of the local Madura chickens, namely Gaok chickens (Arraushany 2017). Even though the number is relatively low, the ayam ketawa bred by the people of Bangkalan has often won the singer chicken contests, beating the ayam ketawa from Sidrap and Jakarta (Sopia and Yuwanto 2016). This may occur because the breeding of ayam ketawa in Bangkalan District has different treatments, such as routine sputum suction in several farm locations, and different environmental factors from the area of origin, so there are differences in the character of the chickens. Mathur (2003) reported that the interaction of genotype and environment will result in different phenotypic expressions from one individual to another depending on environmental conditions. Research on ayam ketawa in Bangkalan District, East Java Province, Indonesia has never been carried out. Therefore, research on bioacoustic, morphometric, and DNA barcoding of ayam ketawa was carried out to know the genetic diversity of ayam ketawa in Bangkalan.

\section{MATERIALS AND METHODS}

\section{Study site}

The research was conducted from June 2017 to June 2018. Bioacoustic and morphometric measurements of twenty samples were carried out in four chicken farms in Bangkalan District, Madura Island, East Java Province, Indonesia (Figure 1), namely: location 1 in Kamal Subdistrict at $7^{\circ} 09^{\prime} 47.7^{\prime \prime} \mathrm{S}, 112^{\circ} 43^{\prime} 11.7^{\prime \prime} \mathrm{E}$, location 2 in Burneh Subdistrict at $7^{\circ} 04^{\prime} 56.4^{\prime \prime} \mathrm{S}, 112^{\circ} 45^{\prime} 11.7^{\prime \prime} \mathrm{E}$, and location 3 in Socah Subdistrict at $7^{\circ} 04^{\prime} 26.4^{\prime \prime} \mathrm{S}$, $112^{\circ} 44^{\prime} 51.5^{\prime \prime} \mathrm{E}$. Analyses of morphometric measurements of the ayam ketawa were carried out at the Genetics Laboratory and Integrated Instrumentation Laboratory of the Department of Biology, FMIPA, Universitas Indonesia, Depok, Indonesia.

\section{Sampling}

The samples for this study were 20 individuals of ayam ketawa, nine of which were collected from Kamal Subdistrict, six from Burneh Subdistrict, and five from Socah Subdistrict. Ayam ketawa in Bangkalan is known to consist of two types: the dangdut type and the slow type. The samples for this study were 20 individuals of ayam ketawa, nine of which were collected from Kamal Subdistrict, six from Burneh Subdistrict, and five from Socah Subdistrict. Ayam ketawa in Bangkalan is known to consist of two types: the dangdut type and the slow type. The morphometric data and the sound of crowing (bioacoustic) were taken from adult male ayam ketawa. Morphometric measurements (Figure 2) were carried out using calipers, iron scales, and gauges. Bioacoustic observations were made through sound recording using a digital camera.

Blood samples were also taken for DNA barcoding analysis. Blood sampling, was performed on the pectoral vein, using a $3 \mathrm{~mL}$ syringe. The blood sample was put into a vacutainer tube containing EDTA (Ethylene diamine tetraacetic acid) then stored in the freezer at $-20^{\circ} \mathrm{C}$. 


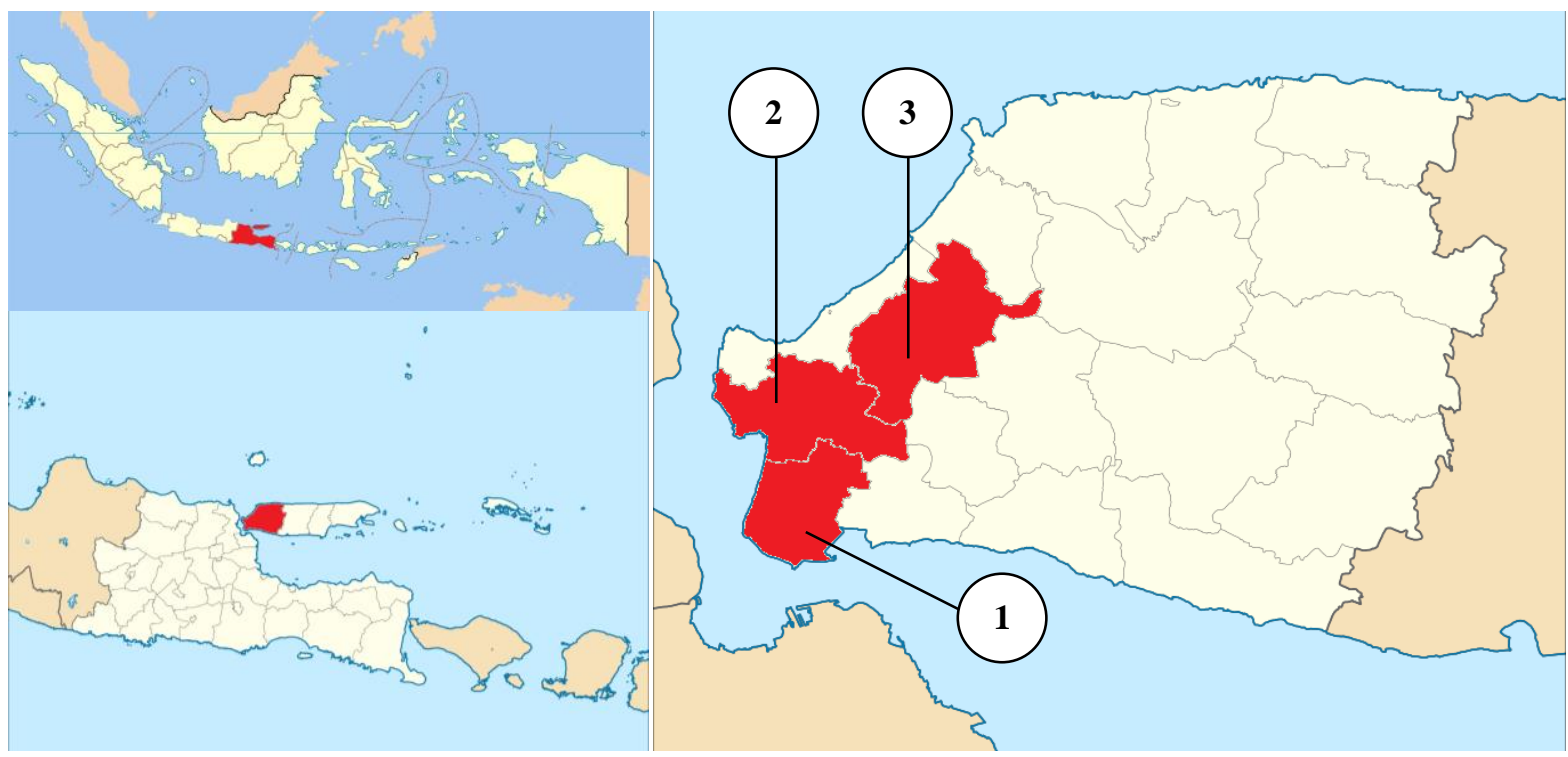

Figure 1. The map of research location in Bangkalan District, Madura Island, East Java Province, Indonesia. 1. Kamal, 2. Socah, 3. Bumeh

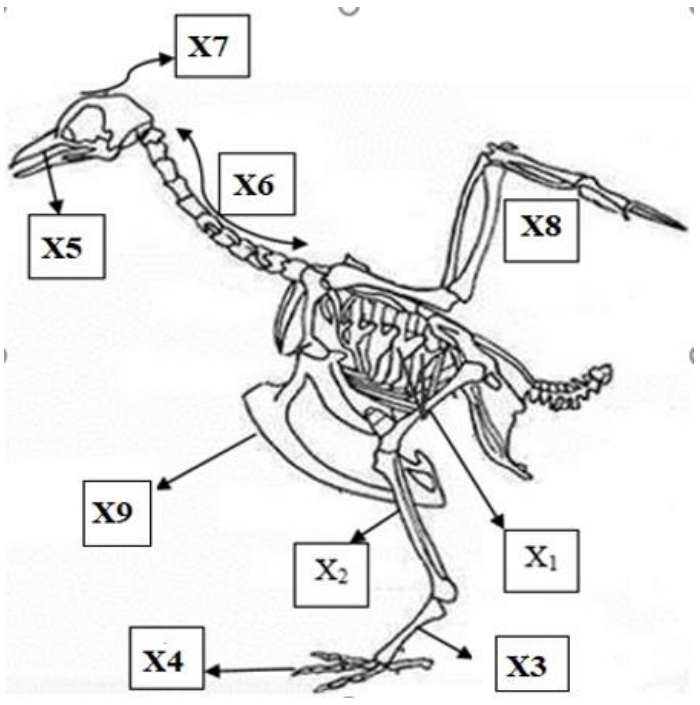

Figure 2. Morphometric character of adult ayam ketawa (Source: Rachma et al. 2013). Note: X1: femur length (mm), X2: tibia length, X3: shank circumference, X4: third finger length, X5: upper maxilla length, 6 : neck bone length, X7: comb height, X8: wing length, X9: breastbone length

\section{Bioacoustic variable measurement (crowing sound)}

The measurement of the sound of rooster crows was done by recording procedure using a digital camera in the morning (08.00-10.00 WIB) (Effendi and Abinawanto 2015). Determination of recording time was adjusted to the habit pattern of ayam ketawa crowing, namely in the morning. The sound of ayam ketawa was recorded with tripod, approximately positioned 0.5 meters away from the sample. At the time of recording, the location was sterile (with no sound of another cock) to avoid bias. Parameters recorded were type of sound, duration of crowing, and number of syllables. The recorded sound results were then analyzed using Cool Edit Pro Portable 2.1 and Ashampoo Music studio 6.0 programs to obtain the duration of crowing and the number of syllables.

\section{Morphometric variables measurement}

Morphometric characters were measured based on research by Abinawanto and Effendi (2017). The morphometric measurements of the ayam ketawa were carried out using calipers, scales, and gauges. Morphometric measurement began with weighing the ayam ketawa to determine body weight using a scale. The measured morphometric characters (Figure 2) were tibia length $(\mathrm{mm})$, wing length $(\mathrm{mm})$, neck bone length $(\mathrm{cm})$, upper maxilla length $(\mathrm{mm})$, femur length $(\mathrm{mm})$, body weight $(\mathrm{g})$, shank length $(\mathrm{cm})$, shank circumference $(\mathrm{cm})$, comb height $(\mathrm{mm})$, and third finger length $(\mathrm{mm})$. The length of the femur (mm), shank ( $\mathrm{mm})$, and sternum $(\mathrm{mm})$ was measured using a caliper. The length of the tibia ( $\mathrm{mm}$ ) was measured using a caliper from the patella to the tip of the tibia, the length of the third finger $(\mathrm{mm})$ from the phalanges to the tip of the finger, length of the upper maxilla $(\mathrm{mm})$ from the base to the tip of the upper half of maxilla, the length of the wing bones $(\mathrm{mm})$ from the base of the humerus to the end of the phalanges, the length of the neck bone $(\mathrm{mm})$ from the end of the neck bone at the base to the end of the neck, and the comb height (mm) from the top of the comb to the bottom of the comb, and the comb height $(\mathrm{mm})$ from the top of the comb to the bottom of the comb. The circumference of the shank ( $\mathrm{mm}$ ) was measured by wrapping around the middle of the shank using a measuring tape.

\section{DNA extraction}

Mitochondrial DNA extraction was carried out using PCR KIT TIANamp Blood DNA Kit which has been 
carried out by Effendi (2017). The blood sample was 5-20 $\mu \mathrm{L}$. It was added with GS buffer until the volume became $200 \mu \mathrm{L}$, and then $20 \mu \mathrm{L}$ of proteinase $\mathrm{K}$ was added, which functioned to lyse red blood cells so that the red blood cell walls were damaged. $200 \mu \mathrm{L}$ of GB buffer was then added and it was incubated at $56^{\circ} \mathrm{C}$ for 10 minutes. Absolute ethanol $(96 \%)$ as much as $200 \mu \mathrm{L}$ was added and it was then vortexed for 20 seconds. The solution was transferred to a spin column $\mathrm{CB} 3$ (in $2 \mathrm{~mL}$ collection tubes), and centrifuged at $12000 \mathrm{rpm}$ for 30 seconds. The resulting filtrate was discarded, and the spin column CB3 was placed back in the collection tube. As much as $500 \mu \mathrm{L}$ of buffer GD (which has been added with $17 \mathrm{~mL}$ of ethanol 96\%) was added, and it was centrifuged at $12000 \mathrm{rpm}$ for 30 seconds. The filtrate was removed, and the spin column CB3 was placed back in the collection tube. As much as $600 \mu \mathrm{L}$ of PW buffer was added, and it was then centrifuged at $12000 \mathrm{rpm}$ for 30 seconds. The formed filtrate was discarded, and the spin column CB3 was placed in the collection tube. Buffer PW (which has been added with $60 \mathrm{~mL}$ of ethanol 96\%) was added as much as $600 \mu \mathrm{L}$, and then centrifuged at a speed of $12000 \mathrm{rpm}$ for 30 seconds. The formed filtrate was discarded, and then the spin column CB3 was placed into the collection tube (the lid of spin-column CB3 was left open for a few minutes so that the membrane dried). The spin-column CB3 was then transferred to a $1.5 \mathrm{~mL}$ tube (microcentrifuge), and 50--200 $\mu \mathrm{L}$ of $\mathrm{TB}$ buffer was added. It was then incubated at room temperature $\left(15-25{ }^{\circ} \mathrm{C}\right)$ for $2-5$ minutes and centrifuged at $12000 \mathrm{rpm}$ for 2 minutes. The filtrate in the form of a DNA sample was accommodated in a $1.5 \mathrm{~mL}$ tube.

\section{DNA amplification}

Areas of $643 \mathrm{bp}$ were amplified using forward BirdF1 primers (5' TTCTCCAACCACAAAGACATTGGCAC 3'), and reverse primers BirdR1 (5 'ACGTGGGAGATAA TTCCAAATCCTG 3') (Hebert et al. 2004). Mastermix PCR 12.5 $\mu \mathrm{L}$, ddH2O / NFW (1.5 $\mu \mathrm{L})$, BirdF1 Primers (1.5 $\mu \mathrm{L})$, BirdR1 $(1.5 \mu \mathrm{L})$, and DNA extracted samples $(8 \mu \mathrm{L})$. According to Bondoc and Santiago (2012), and Bondoc (2013), the PCR amplification stage starts from predenaturation of $94{ }^{\circ} \mathrm{C}$ for 3 minutes, denaturation of 94 ${ }^{\circ} \mathrm{C}$ for 40 seconds, Annealing $56{ }^{\circ} \mathrm{C}$ for 30 seconds, extension to $72{ }^{\circ} \mathrm{C}$ for 45 seconds, pre-extension to $72{ }^{\circ} \mathrm{C}$ for 7 minutes. The amplification results were verified with electrophoresis using $1.5 \%$ agarose gel, added with $1 \mu \mathrm{L}$ of red gel.

\section{Electrophoresis}

Electrophoresis was carried out on $1.5 \%$ agarose gel which was added with $1 \mu \mathrm{L}$ of red gel. Then each well contained $4 \mu \mathrm{L}$ of DNA samples and $1 \mathrm{~mL}$ of DNA loading dye, while the well marker contained $1 \mu \mathrm{L}$ of DNA Ledder, $1 \mu \mathrm{L}$ of DNA loading dye, $4 \mu \mathrm{L}$ of NFW with a voltage of 100 volts, for 30 minutes. DNA profiles were documented using the GelDoc tool.

\section{Sequencing}

PCR product sequencing was done by company providing the service for mitochondrial DNA sequencing.
Sequencing results can be viewed manually with the sequence navigator program (Applied Biosystem).

\section{Data analysis \\ Bioacoustic}

The results of measuring the number of syllables and duration of crowing were obtained through the Cool Edit Pro Portable 2.1 software (Bugiwati and Ashari 2013) and Ashampoo Music studio 6.0 and were analyzed descriptively (Figure 3).

\section{Morphometric}

The results of morphometric measurements were analyzed using the Kruskal-Wallis, Mann-Whitney test, and multiple linear regression analysis in the SPSS 16.0 program (Effendi 2017).

Kruskal-Wallis test. The Kruskal-Wallis test was carried out to identify which characters showed significant differentiation in the entire population of ayam ketawa in Bangkalan District.

The formula used for the Kruskal-Wallis test is (Sheskin 2011):

$$
H=\frac{12}{n(n+1)} \sum_{i=1}^{k} \frac{R_{i}^{2}}{-3(n+1)}
$$

Where:

H: Kruskall-Wallis test value

$\mathrm{n}$ : Number of samples

$\mathrm{R}$ : The total range of all data groups

Mann-Whitney test. The two-way test using the MannWhitney test was intended to determine the morphometric differentiation between different populations (one population with another) from the ayam ketawa species found in several areas in Bangkalan District, Madura. The formula for determining the U value is as follows (Sheskin 2011):

$$
\begin{aligned}
& U_{A}=n_{a} n_{b}+\frac{n_{a}\left(n_{a}+1\right)}{2}-R_{A} \\
& U_{B}=n_{a} n_{b}+\frac{n_{b}\left(n_{b}+1\right)}{2}-R_{B} \\
& \text { Where: } \\
& \text { UA : U value for population A. } \\
& \text { na : number of members of the population a } \\
& \mathrm{R} \quad: \text { The sum of the rating values of population } \\
& \mathrm{UB}: \text { U value for population } \mathrm{B} \\
& \mathrm{nb}: \text { number of members of the population } \mathrm{b}
\end{aligned}
$$

Multiple Linear Regression Analysis. Multiple regression analysis predicts the effect value of two or more independent variables on one dependent variable. It is to prove the presence of relationship between the two or more independent variables $\mathrm{X} 1, \mathrm{X} 2, \mathrm{X} 3, \ldots ., \mathrm{Xi}$ against one dependent variable $Y$. This analysis was used to see the relationship between bioacoustic characters and morphological characters in all samples of ayam ketawa collected from several locations in Bangkalan District. 
Regression analysis general equation (Sheskin 2011):

$$
Y i=\beta_{0}+\beta_{i} X_{i 1}+\beta_{2} X_{i 2}+\ldots+\beta_{k} X_{i k}+\varepsilon_{i}
$$

Where:

$Y i$ : dependent variable for $\mathrm{i}^{\text {th }}$ observation $=1^{\text {st }}, 2^{\text {nd }}, \ldots, \mathrm{n}^{\text {th }}$

$\beta_{0}, \beta_{1}, \ldots, \beta_{k} \quad$ : parameter

$X_{i 1}, X_{i 2}, \ldots, X_{i k}:$ independent variable

$\varepsilon_{i} \quad:$ remainder $(\varepsilon)$ for the $\mathrm{i}^{\text {th }}$ observation

\section{Phylogeny analysis}

The nucleotide sequences from the result of DNA sequences were then aligned with the BioEdit program from the European Bioinformatics Institute http://www.ebi.ac.uk/serve/clustalw). The edited DNA sequences were then aligned using DNA sequence information available in GenBank (http://www.ncbi.nlm.nih.gov) from species of one genus or family that other researchers have sequenced. The process of aligning nucleotides used ClustalW which was available in the MEGA 7.0 program. The program would automatically mark the bases in the nucleotide sequences of other sequenced species. The electropherogram resulting from sequencing could not be used directly, especially when there were coinciding peaks, the peaks were too short or some nucleotides were missing. Then, the electropherogram was manually edited again. The analysis included the calculation of nucleotide composition, substitution rate, and genetic distance. Calculation of the value of genetic distance between one individual and another used the Kimura 2 Parameter (K2P) substitution model in the MEGA (Molecular Evolutionary Genetics Analysis) software Version 5 (Tamura et al. 2011). The phylogeny tree reconstruction was carried out using the Neighborhood Joining ( $\mathrm{NJ}$ ) method with a bootstrap test of 1000 times (Nei and Kumar 2000).

\section{RESULTS AND DISCUSSION}

\section{Bioacoustic of Ayam Ketawa}

The difference in the type of sound in ayam ketawa was based on the presence or absence of a "cengkokan (bending)" at the end of the crowing. In the slow type of ayam ketawa there is a "cengkokan (bending)" at the end of the crowing, and it usually consists of one syllable. The "cengkokan (bending)" in the slow type of ayam ketawa is a rhythmic decoration at the end of the crowing. The dangdut type of ayam ketawa does not have a "cengkokan (bending)". The rhythm of the crowing in the slow ayam ketawa tends to be more rhythmic when compared to the dangdut type which tends to be fast. In its origin, Sidrap District, the dangdut type of ayam ketawa is divided into two, namely the long dangdut type and the short dangdut type (Bugiwati and Ashari 2013).

The crowing of the singer type is generally the same, for example, the crowing of ayam ketawa and the crowing of ayam kokok bacengkok ( $A K B)$, both consist of 3 parts, namely the first part, namely the first prefix syllable, the second part consisting of several syllables, and the last part consisting of an end crowing sound in the form of "cengkokan (bending)" (Rusfidra 2006). But, there is no "cengkokan (bending)" in the dangdut type of ayam ketawa. Dangdut type of ayam ketawa also tends to have the same crowing rhythm from the beginning to the end, which contrasts with the slow type of ayam ketawa and AKB.

Table 1 shows that ayam ketawa from Kamal Subdistrict has the longest average duration of crowing, namely $6.00 \pm 3.0$ seconds, while the highest average number of syllables comes from the ayam ketawa of Socah Subdistrict, namely 7.20 \pm 5.80 . These results indicate that ayam ketawa in Bangkalan District has a longer crowing duration than the local non-ayam ketawa which only reaches an average of 3.609 seconds. While Table 2 shows that the longest duration of crowing in a dangdut type of ayam ketawa comes from Burneh Subdistrict with $4.65 \pm$ 0.35 seconds and the longest duration in slow type of ayam ketawa is from Kamal Subdistrict with a duration of $8.04 \pm$ 2.55 seconds.

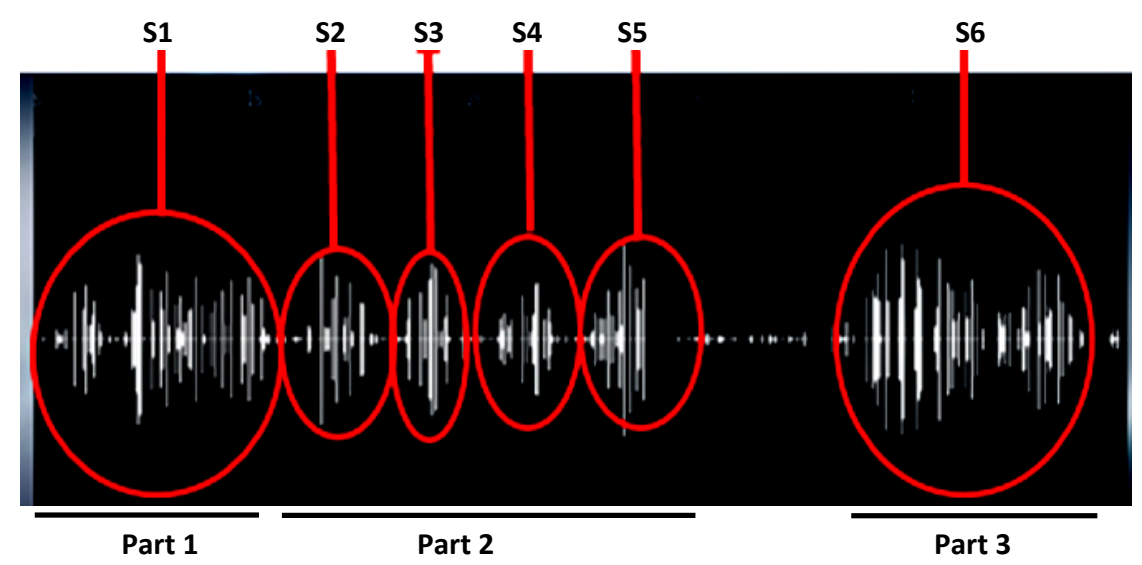

Figure 3. Visualization of the number of syllables from the recorded voice of the slow type of ayam ketawa. Note: S: Syllables, Part 1 is a prefix of crow (S1), Part 2 is the main crow (S2, S3, S4, S5), Part 3 is the ending crow or crooked (S6), consists of one syllable, only owned by slow type of ayam ketawa 
Table 2 shows that the dangdut type of ayam ketawa in Kamal Subdistrict has the highest number of syllables, namely $10.5 \pm 5.80$ seconds. In comparison, it is $11.75 \pm$ 1.70 seconds for the slow type of ayam ketawa in Burneh Subdistrict. The difference between the length and duration is not necessarily proportional to the number of syllables, because each individual has a different crowing capacity and ability. The difference in location and treatment in the upkeep also affects the ability of the ayam ketawa to crow.

The number of ayam ketawa syllables in Bangkalan District is more than that in the Pinrang District area. Abinawanto and Effendi (2017) reported that the number of syllables in the slow type of ayam ketawa in Pinrang District was 3-5 and in the dangdut type 4-7. The length of the duration and the number of crowing syllables of each laughing cock are influenced by the training period of each individual. This is in accordance with the statement of Marler and Doupe (2000) that the ability to crow in singing chickens is not genetically inherited, but is culturally inherited through the training phase. The practicing phase of crowing in chickens occurs in two phases: the sensory phase and the sensory-motor phase. During the sensory phase, the young rooster will watch the older male crowing and make it as a reference. The young rooster will record that sound of crowing which is used as a reference. In the sensory phase, the organ that regulates sound production called the song control region (SCR) undergoes development. The sensory-motor phase occurs after the rooster experiences sexual maturity. At this time, the adult rooster begins to sing and train continuously until it becomes a proficient singing chicken.

\section{Morphometric of ayam ketawa}

In general, ayam ketawa in Kamal Subdistrict has the largest body size with bodyweight of $1.96 \pm 0.65 \mathrm{~kg}$, tibia length $122.64 \pm 24.77 \mathrm{~mm}$, shank length $94.68 \pm 8,85 \mathrm{~mm}$, shank circumference $56.77 \pm 11.44 \mathrm{~mm}$, wing length $239.56 \pm 24.40 \mathrm{~mm}$, third finger length $52.53 \pm 2.45 \mathrm{~mm}$, sternum length $116.96 \pm 13.10 \mathrm{~mm}$, and comb height 34.97 $\pm 16.96 \mathrm{~mm}$. The ayam ketawa in Socah Subdistrict ranks second with the length of the upper maxilla of $30.80 \pm 1.55$ $\mathrm{mm}$, the femur length $105.60 \pm 8.68 \mathrm{~mm}$, and the length of the neck bone $74.99 \pm 15.70 \mathrm{~mm}$ (Table 3). The ayam ketawa in Burneh Subdistrict has the smallest body size with neck bone length of $70.14 \pm 7.93 \mathrm{~mm}$, bodyweight $1.30 \pm 0.18 \mathrm{~mm}$, femur length $86.62 \pm 14.73 \mathrm{~mm}$, tibia length $112.01 \pm 9.25 \mathrm{~mm}$, shank length $82.51 \pm 7.56 \mathrm{~mm}$, shank circumference $46.16 \pm 5.84 \mathrm{~mm}$, maxilla length of $27.05 \pm 2.73 \mathrm{~mm}$, wing length $213.33 \pm 8.16 \mathrm{~mm}$, comb height of $15.59 \pm 5.59 \mathrm{~mm}$, third finger length $42.87 \pm 5.67$ $\mathrm{mm}$, and sternum length $98.69 \pm 13.52 \mathrm{~mm}$ (Table 3 ).

The Kruskal-Wallis analysis of the whole samples of ayam ketawa showed that five out of eleven characters tested were significantly different $(\mathrm{P}<0.05)$ among the samples, namely weight, shank circumference, wing length, third finger length, and sternum length (Table 4). Rachma et al. (2013) reported that there was no significant difference between each character of body measurements between ayam ketawa and native chickens (non-ayam ketawa) in Sidrap. However, the body shape of native Indonesian chickens is influenced by the height of the comb, the length of the wings, the length of the femur, and the length of the tibia. It was further explained that the body size of a chicken is characterized by wing length, femur length, tibia length, shank length, and comb height. The difference in body size is influenced by several factors, namely genetics, upkeep methods, treatment, health conditions, and the type of given feed (Gunawan and Sihombing 2004).

Table 1. Description of analysis of bioacoustic sample of all study locations

\begin{tabular}{lccc}
\hline \multirow{2}{*}{ Location } & \multirow{2}{*}{$\begin{array}{c}\text { Number } \\
\text { of } \\
\text { samples }\end{array}$} & $\begin{array}{c}\text { Duration of } \\
\text { crowing } \\
\text { (seconds) }\end{array}$ & $\begin{array}{c}\text { Number of } \\
\text { syllables }\end{array}$ \\
\hline $\begin{array}{l}\text { Kamal } \\
\text { Subdistrict }\end{array}$ & 9 & $6.00 \pm 3.0$ & $10.11 \pm 4.13$ \\
$\begin{array}{l}\text { Burneh } \\
\text { Subdistrict }\end{array}$ & 6 & $4.16 \pm 0.752$ & $9.16 \pm 4.87$ \\
$\begin{array}{l}\text { Socah } \\
\text { Subdistrict }\end{array}$ & 5 & $4.40 \pm 0.89$ & $17.20 \pm 5.80$ \\
\hline
\end{tabular}

Table 2. Description of analysis of bioacoustic sample in all research locations based on the type of sound

\begin{tabular}{|c|c|c|c|}
\hline \multirow[b]{2}{*}{ Location } & \multirow[b]{2}{*}{$\begin{array}{c}\text { Type and } \\
\text { number of } \\
\text { samples (n) }\end{array}$} & \multicolumn{2}{|c|}{ Average } \\
\hline & & $\begin{array}{l}\text { Duration of } \\
\text { crowing } \\
\text { (seconds) }\end{array}$ & $\begin{array}{l}\text { Duration of } \\
\text { crowing } \\
\text { (seconds) }\end{array}$ \\
\hline Kamal & Dangdut & $4.1 \pm 0.63$ & $10.5 \pm 5.80$ \\
\hline Subdistrict & Slow & $8.04 \pm 2.55$ & $9.5 \pm 2.94$ \\
\hline Burneh & Dangdut & $4.65 \pm 0.35$ & \\
\hline Subdistrict & Slow & $4.37 \pm 0.88$ & $11.75 \pm 1.70$ \\
\hline Socah & Dangdut & $4.6 \pm 0.96$ & $9.5 \pm 7.93$ \\
\hline Subdistrict & Slow & $5.1 \pm 0.28$ & $11 \pm 1.41$ \\
\hline
\end{tabular}

Tabel 3. Morphometric average of ayam ketawa in Bangkalan District, Indonesia

\begin{tabular}{|c|c|c|c|c|c|c|c|c|c|c|c|}
\hline \multirow[b]{2}{*}{ Location $n$} & \multicolumn{11}{|c|}{ Average } \\
\hline & $\begin{array}{c}\text { PTL } \\
(\mathbf{m m})\end{array}$ & $\begin{array}{c}\mathbf{L S} \\
(\mathbf{m m})\end{array}$ & $\begin{array}{l}\text { PMA } \\
(\mathbf{m m})\end{array}$ & $\begin{array}{c}\text { PSa } \\
(\mathbf{m m})\end{array}$ & $\begin{array}{c}\text { TJ } \\
(\mathbf{m m})\end{array}$ & $\begin{array}{c}\text { PJK } \\
(\mathbf{m m})\end{array}$ & $\begin{array}{c}\text { PTD } \\
(\mathbf{m m})\end{array}$ & $\begin{array}{c}\text { BB } \\
(\mathrm{kg})\end{array}$ & $\begin{array}{c}\mathbf{P F} \\
(\mathbf{m m})\end{array}$ & $\begin{array}{c}\text { PT } \\
(\mathbf{m m})\end{array}$ & $\begin{array}{c}\text { PSh } \\
(\mathbf{m m})\end{array}$ \\
\hline
\end{tabular}

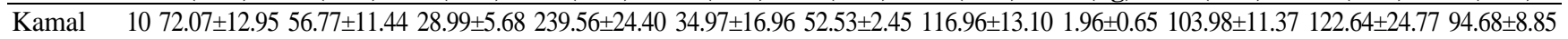

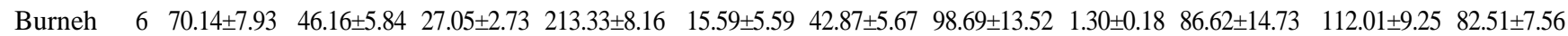

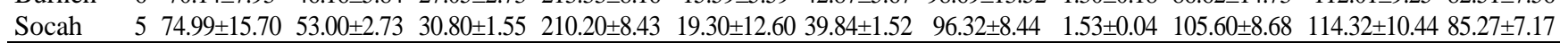
Note: number of samples (n), neck bone length (PTL), shank circumference (LS), upper maxilla length (PMA), wing length (PSa), comb height (TJ), third finger length (CHD), sternum length (PTD), body weight (BB), femur length (PF), tibia length (PT), shank length (PSh) 
The differentiation of morphological characters between the two populations shown in Mann-Whitney test (Table 6) shown in Mann-Whitney test (Table 6) is assumed to be due to differences in their habitat and utilization by humans around the sampling location in each population (Table 5). Differences in habitat and area used for human activities affect the differentiation of the morphological characters of the ayam ketawa (Noerjanto 2007). There are significant differences in morphology in the population of Kamal Subdistrict and Burneh Subdistrict, because the population of Kamal Subdistrict is in a low human activity environment, while the population in the Burneh Subdistrict is close to the main road, and local tourist areas, so there are high human activities, causing high stress levels in ayam ketawa. In addition, high environmental temperatures in Burneh Subdistrict can also put stress for poultry. High-stress levels cause the ayam ketawa to lose appetite for food and continuously defecate until they experience a decrease in body weight (Cooper and Washburn 1988).

The lack of the influence of anthropogenic activity and the similar temperature in Kamal Sub-district and Socah Sub-district make these populations of the two subdistricts had had few number of differentiated characters. Meanwhile, the differentiation of morphological characters in the population in Socah Subdistrict and Burneh Subdistrict is assumed to be due to temperature differences. The optimal temperature for raising ayam ketawa is 26$30^{\circ} \mathrm{C}$. Too high temperature causes the chicken to experience hyperthermia. To reduce excess heat in the body, chickens accelerate the respiratory rate (panting) and consume more water than feed (Cooper and Washburn 1988; Gunawan and Sihombing 2004), therefore there are significant differences in body weight, femur length, and shank circumference.

The diversity of research results was also reported by Andrianto (2015) that the ayam ketawa from Kendari had rooster body sizes with the highest diversity coefficient (DC) was neck length $(\mathrm{DC}=11.47 \%)$, then the length of the third finger $(\mathrm{DC}=11.10 \%)$, sternum length $(\mathrm{DC}=$ $10.68 \%)$, and shank circumference $(\mathrm{DC}=10.16 \%)$. This means that the characters of neck length, third finger length, sternum length, and shank circumference have a higher diversity than other characters.

Table 4. Results of the Kruskal-Wallis analysis on the entire population of ayam ketawa

\begin{tabular}{lll} 
Characters & $\mathbf{X}^{\mathbf{2}}$ & $\mathbf{P}$ \\
\hline Neckbone length & 1.710 & $0.425^{\mathrm{ns}}$ \\
Bodyweight & 9.777 & $0.008^{\mathrm{a} *}$ \\
Femur length & 7.042 & $0.30^{\mathrm{ns}}$ \\
Tibia length & 0.556 & $0.757^{\mathrm{ns}}$ \\
Shank length & 7.961 & $0.19^{\mathrm{ns}}$ \\
Shank circumference & 7.422 & $0.024^{\mathrm{a}^{*}}$ \\
Upper maxilla length & 2.985 & $0.225^{\mathrm{ns}}$ \\
Wing length & 10.805 & $0.004^{\mathrm{a} *}$ \\
Comb height & 6.509 & $0.039^{\mathrm{ns}}$ \\
Third finger length & 11.736 & $0.003^{\mathrm{a} *}$ \\
Sternum length & 10.744 & $0.005^{\mathrm{a}}$ \\
\hline Note X2
\end{tabular}

Note: $\mathrm{X}^{2}$ is the value of chi-square, $\mathrm{P}$ is the value of Asymp. Sig. The a value indicates $P$-value $<0.05$, which means that the parameter value is significantly different from the overall population

Table 6. Morphological characters based on the analysis of variations between populations

\begin{tabular}{lccc}
\hline \multirow{1}{*}{ Character } & \multicolumn{3}{c}{ Location } \\
\cline { 2 - 4 } & $\begin{array}{c}\text { Kamal and } \\
\text { Burneh }\end{array}$ & $\begin{array}{c}\text { Kamal and } \\
\text { Socah }\end{array}$ & $\begin{array}{c}\text { Burneh and } \\
\text { Socah }\end{array}$ \\
\hline Neckbone length & $0.238^{\mathrm{ns}}$ & $0.463^{\mathrm{ns}}$ & $0.464^{\mathrm{ns}}$ \\
Body weight & $0.013^{\mathrm{a} *}$ & $0.095^{\mathrm{ns}}$ & $0.006^{\mathrm{a} *}$ \\
Femur length & $0.018^{\mathrm{a} *}$ & $0.641^{\mathrm{ns}}$ & $0.028^{\mathrm{a} *}$ \\
Tibia length & $0.480^{\mathrm{ns}}$ & $0.641^{\mathrm{ns}}$ & $0.855^{\mathrm{ns}}$ \\
Shank length & $0.013^{\mathrm{a} *}$ & $0.039^{\mathrm{a} *}$ & $0.465^{\mathrm{ns}}$ \\
Shank circumference & $0.020^{\mathrm{a} *}$ & $0.150^{\mathrm{ns}}$ & $0.047^{\mathrm{a}^{*}}$ \\
Upper maxilla length & $0.289^{\mathrm{ns}}$ & $0.549^{\mathrm{ns}}$ & $0.068^{\mathrm{ns}}$ \\
Wing length & $0.006^{\mathrm{a}}$ & $0.008^{\mathrm{a} *}$ & $0.641^{\mathrm{ns}}$ \\
Comb height & $0.018^{\mathrm{a} *}$ & $0.072^{\mathrm{ns}}$ & $1.000^{\mathrm{ns}}$ \\
Third finger length & $0.018^{\mathrm{a} *}$ & $0.003^{\mathrm{a} *}$ & $0.144^{\mathrm{ns}}$ \\
Sternum length & $0.013^{\mathrm{a} *}$ & $0.003^{\mathrm{a} *}$ & $0.100^{\mathrm{ns}}$ \\
\hline
\end{tabular}

Note: The value shown is the P-value, the results of the MannWhitney test. The value of a shows P-value $<0.05$, which means that the parameter value is significantly different in the two populations.

Table 5. The condition of the farming environment at the sampling location in Bangkalan District, Indonesia

\begin{tabular}{lccll}
\hline Location & Temperature & $\begin{array}{c}\text { Altitude } \\
(\mathbf{m} . \text { asl })\end{array}$ & \multicolumn{1}{c}{ Condition of the farm } & Feed \\
\hline $\begin{array}{l}\text { Kamal } \\
\text { Subdistrict }\end{array}$ & $30^{\circ} \mathrm{C}$ & 5 & $\begin{array}{l}\text { A stable farm area on dense sandy red soil, located in a non- } \\
\text { densely populated settlement, shaded by a tree with a crown of } \\
\text { about } 5 \text { meters, once a week of sputum suction treatment, the } \\
\text { chickens confined in an enclosed environment }\end{array}$ & $\begin{array}{l}\text { Bran, flour, protein, } \\
\text { vitamins }\end{array}$ \\
$\begin{array}{l}\text { Burneh } \\
\text { Subdistrict }\end{array}$ & $32^{\circ} \mathrm{C}$ & 10 & $\begin{array}{l}\text { A stable asphalt farm area, without trees, close to the main } \\
\text { road, and the Jaddih Hill tourist area, and the chickens raised in } \\
\text { an open environment }\end{array}$ & $\begin{array}{l}\text { Bran, vegetables, } \\
\text { vitamin concoction }\end{array}$ \\
$\begin{array}{l}\text { Socah } \\
\text { Subdistrict }\end{array}$ & $30^{\circ} \mathrm{C}$ & 7.5 & $\begin{array}{l}\text { A stable farm area on clay soil, many trees around, located in a } \\
\text { plantation, the chickens released in the house yard, away from } \\
\text { the main road, in an open environment }\end{array}$ & $\begin{array}{l}\text { Bran, protein flour, } \\
\text { vitamins, concoction } \\
\text { of Ginger and honey }\end{array}$ \\
\hline
\end{tabular}


The results of multiple linear regression analysis showed, showed that several morphological characters of the ayam ketawa were positively correlated with high a coefficient of correlation, namely body weight with neck bone length $(r=0.87)$, bodyweight with shank circumference $(r=0.77)$, and body weight with sternum length $(r=68)$. These research results are in accordance with the results of research by Rusdin et al. (2011) which states that neck length has a highly significant positive correlation with body weight and shank circumference in male Tolaki chickens.

The PCR results showed migration of DNA bands on the $1.5 \%$ agarose gel, 100 Volt voltage, for 30 minutes, shown in Figure 4 through the visualization of the Gel doc tool. The COI region produced $643 \mathrm{bp}$ of DNA fragments in all samples (Figure 5). Twenty samples that were successfully sequenced were from Kamal Sub-district (AD01, AD02, AD03, AD04, AS01, AS02, AS03, AS04, AS05), Burneh Sub-district (BS01, BS02, BS03, BS04, BD01, BD02), and Socah Sub-district (CD01, CD02, CD03, CS01, CS02) are amplified by BirdF1 forward primers and BirdR1 reverse primers.

Primers are specific oligonucleotides in a short DNA template. Primers attach to the DNA template at a specific place. During PCR, new DNA is printed with the aid of the polymerase enzyme and then amplified. The optimal gene amplification in chicken blood samples occurs at $56^{\circ} \mathrm{C}$ for 30 seconds (Bondoc and Santiago 2012), and results in a PCR product of $643 \mathrm{bp}$. Optimal temperature is needed because in this process the primer will stick to the target DNA.
The success of the amplification process can also be caused by the concentration of DNA. A good DNA concentration is equivalent to $50 \mu \mathrm{g} / \mathrm{mL}$, and with a purity of $1.8 \leq \mathrm{x} \leq 2.0$. The concentration used in this study ranged from $133-400 \mu \mathrm{g} / \mathrm{mL}$, with a purity of 1.76-2.01. After the PCR results were obtained, they can be immediately visualized with electrophoresis and then be viewed using a GelDoc.

The obtained DNA bands were checked for conformity with the size of the target genes. It is known that the size of the COI gene in chickens has a length of 500-700 bp. After the DNA band according to the size of target gene was obtained, the next step is sequencing to see the arrangement of the DNA nucleotide bases. The sequencing data used the COI gene marker in the form of a chromatogram. The chromatogram was then analyzed using BLAST. The BLAST results show that the obtained sequences are true COI gene sequences, whose length of DNA fragments is around 643-650 bp.

Another sequence that was taken and made into an outgroup in this study was Gallus varius (Genbank AP003324). Gallus varius is green jungle fowl originating from Java. Previously, the green jungle fowl (G. varius) and the Sumatran red jungle fowl (G. gallus gallus) were identified as the ancestors of the native chicken ( $G$. gallus domesticus). Gallus varius has lower adaptability than $G$. g. gallus, leading to the decline in the population of $G$. varius, and resulting in increasingly uncontrolled interspecies mating, so the genetic distance of the existing native chickens of the red jungle fowl is closer than that in the green jungle fowl (Mansjoer 1985).

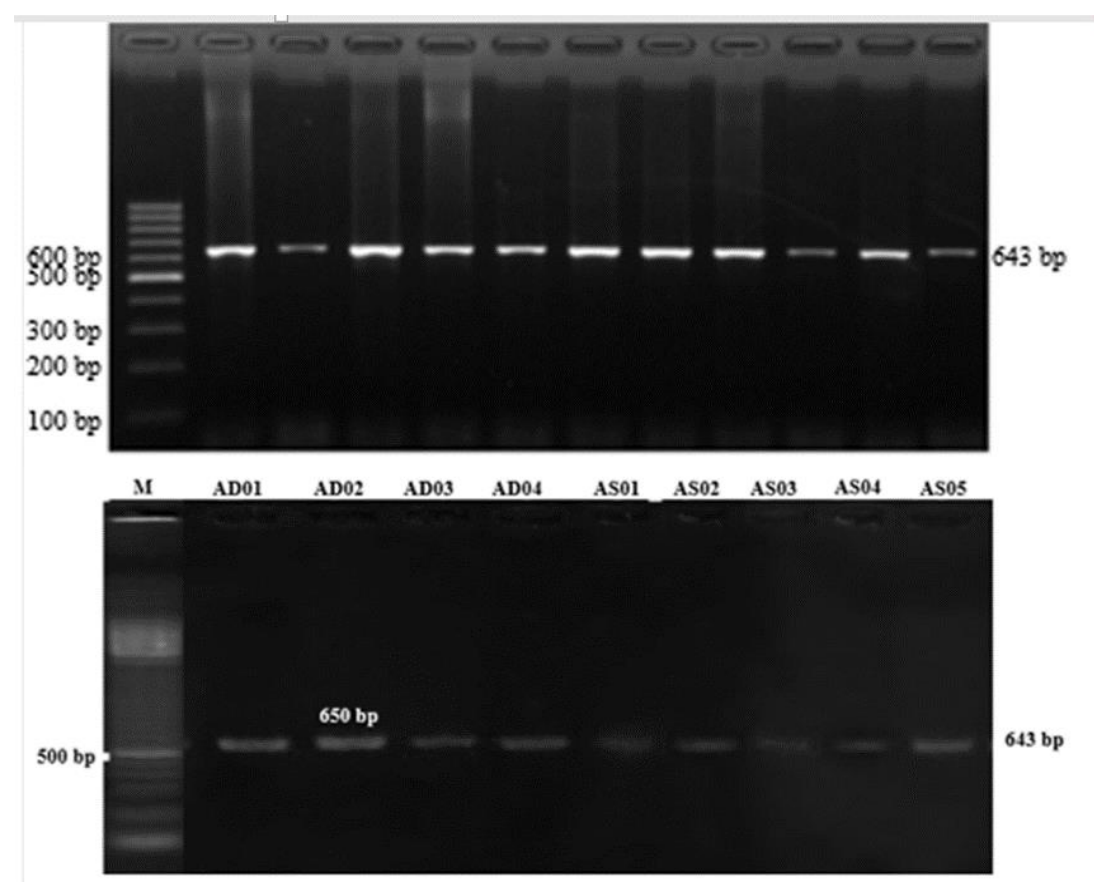

Figure 4. Visualization of the ayam ketawa CO1 gene in Bangkalan District, Madura Island, Indonesia on agarose gel $1.5 \%$; $100 \mathrm{~V} ; 30$ min. Note: M: Marker, AS: Slow type sample in Kamal Subdistrict, AD: Dangdut type sample in Kamal Subdistrict, BS: Slow type sample in Burneh Subdistrict, BD: Dangdut type sample in Burneh Subdistrict, CS: Slow type sample in Socah Subdistrict, CD: Dangdut type sample in Socah Subdistrict 
Reconstruction of the ayam ketawa (G. g. domesticus) phylogeny tree was carried out to determine the relationship between groups of ayam ketawa in Bangkalan District. Apart from an initial technique for reconstructing the phylogeny tree, the DNA barcoding technique has also been shown to be effective in identifying all samples. The Cytochrome Oxidase Sub Unit 1 (COI) gene has successfully been identified as a marker in the DNA barcoding technique. The use of DNA barcoding techniques using COI derived from Mitochondrial DNA has also been successfully carried out in other species, namely Gallus gallus philippensis in the highlands of the Philippines (Bondoc and Santiago 2012; Bondoc 2013). Gene analysis using genes derived from mitochondrial DNA has an excellent approach to solving taxonomic problems regarding chicken taxonomy, species identification, and population genetics (Hebert et al. 2004). Mitochondrial DNA has a large copy number, so the amplification results will be maximized.

The phylogeny tree reconstruction of the ayam ketawa population was carried out based on the nucleotide sequence of mitochondrial DNA. This segment has a high rate of evolution compared to other regions, so this segment has more polymorphic sites useful in reconstructing intraspecific phylogeny trees. This phylogeny tree was formed using the Neighbor-Joining method which is the distance method with the principle of grouping taxa based on evolutionary distance values (Hartl 2000).

The reconstruction of the phylogeny tree (Figure 5) shows the phylogeny relationship of the ayam ketawa of genus Gallus (Gallus gallus domesticus) in Bangkalan District. The reconstruction of the phylogeny tree requires sequences of other species of the genus Gallus as outgroups. Additional sequence data were taken from GenBank. The added outgroup should be closely correlated with the analyzed sequences and have a significant difference with the other sequences among the sequences themselves. Selection of outgroup sequences that are too far can lead to phylogenetic tree prediction errors, resulting in more random sequence differences between outgroup sequences and other sequences.

The kinship relationship among the 20 haplotypes of ayam ketawa (Figure 5) shows that the haplotypes AS01 with AS04, CD01 with CD02, CS01, CS02, CD03, and AD03, AS02, AS03, AD04, AS01, AS04 show a high bootstrap value namely 1000 , whereas, on the other nodes, the smallest bootstrap value is 382 . The bootstrap value is the benchmark for determining the level of trustworthiness of the phylogeny tree. The bootstrap method in determining tree confidence levels is based on the fact that the distribution of characters in the data is influenced by random effects (stochastic). With a number of replicated data sets generated by the bootstrap method, it is possible to estimate how much the random effect affects the tree, especially its topology. Based on this, the percentage value of the bootstrap method replication results is also called the bootstrap value, which is used as a benchmark for determining the level of trust of the tree. The greater the bootstrap value, the higher the trust level of the reconstructed tree topology (Nei and Kumar 2000). In addition, the bootstrap value in the phylogeny tree also determines the stability of the evolutionary process between groups (clades). The tree shows that the population of ayam ketawa in Bangkalan District is separated into two groups with quite high stability, namely the bootstrap value of 943 . The value of genetic distance supports grouping, the closeness of each individual in the population, and between these groups and differences in nucleotides.

The genetic distance as the basis for the reconstruction of phylogeny trees produced in this study was based on the 20 haplotypes identified from the population of ayam ketawa in Bangkalan District, which ranged from 0.025 to 1.722 (Table 7). Kumar et al. (2004) reported that phylogeny trees could be generated using the MEGA (Molecular Evolutionary Genetics Analysis) software Version 7.0. The results of research on native chickens conducted by Rangkuti et al. (2016) showed that the genetic distance of native chickens in Labuhan Batu District was between 0.048-2.736, while Bondoc and Santiago (2012) reported the genetic distance of native chickens ( $G$. gallus domesticus) in the Philippines was between $0.019-1.367$. This means that the genetic distance of the chicken population in Bangkalan District is higher than the range of the native chicken in the Philippines and lower than that in the native chicken population in Labuhan Batu District. The high genetic distance in ayam ketawa indicates that there is high inter-individual variation in Bangkalan District. External differences such as temperature and altitude as well as food and care produce an adaptation process resulting in variations between individuals and groups (Bondoc 2013). The farthest genetic distance of ayam ketawa (G. g. domesticus) (Figure 5) was found in ayam ketawa population of Kamal Subdistrict with ayam ketawa population of Socah Subdistrict, namely 1.722. The closest genetic distance was found between the population of Kamal Subdistrict and that of Burneh Subdistrict, namely 0.142 .

Although the geographical position of Kamal Subdistrict is closer to Socah Subdistrict than to Burneh Subdistrict, the genetic distance between the population in Kamal Subdistrict and in Socah Subdistrict was the greatest. Differences in environmental conditions, (Table $5)$, indirectly affect variations between populations. In the population of Socah Subdistrict, ayam ketawa are kept roaming freely in the yard of the house. It does not rule out the possibility of crossing with other native chickens, so the genetic diversity and population expansion in ayam ketawa in Socah Subdistrict is high.

In conclusion, ayam ketawa populations from three subdistricts in Bangkalan District had different bioacoustics, morphometric and DNA barcoding characters. 


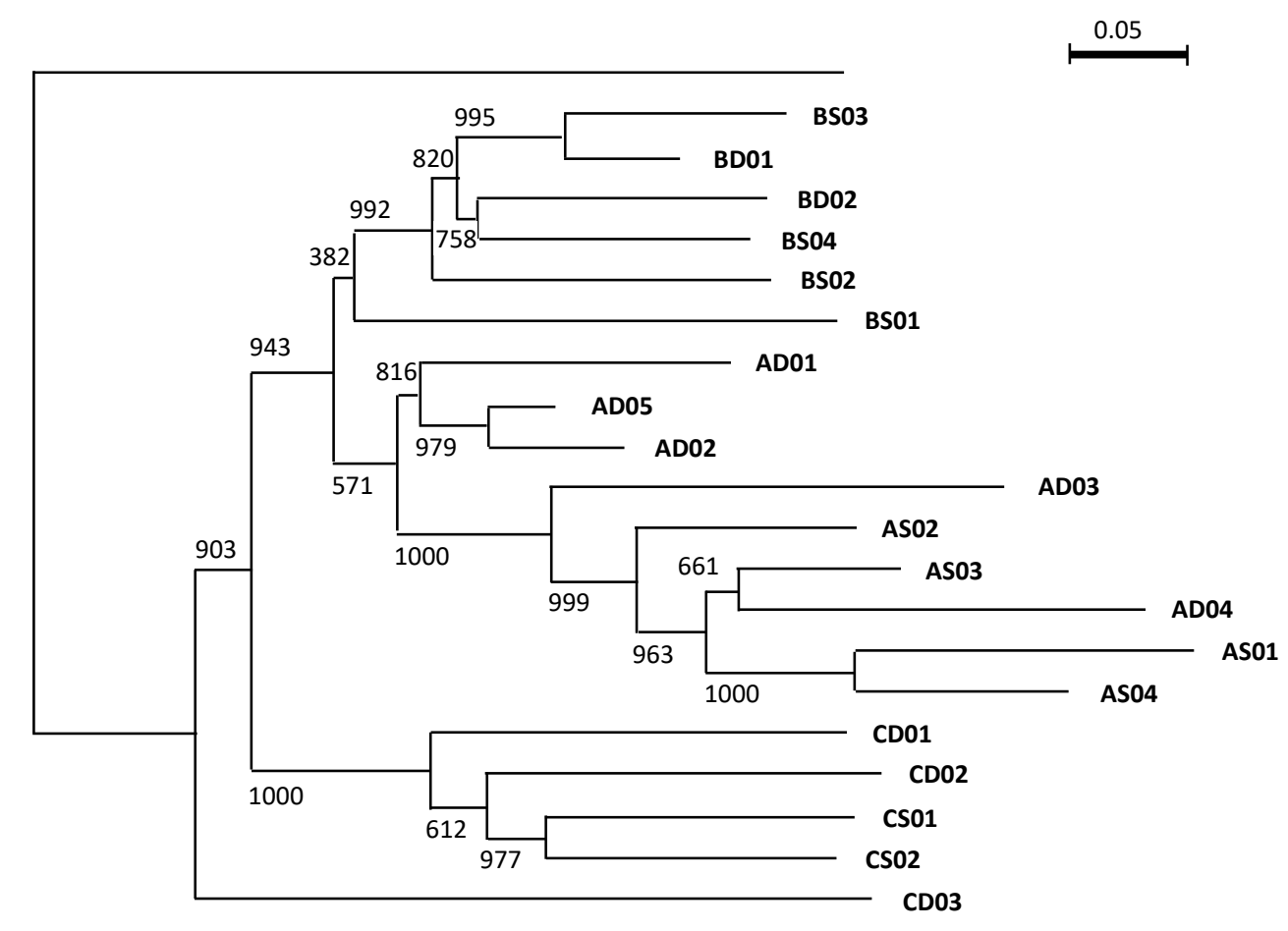

Figure 5. Ayam ketawa phylogenetic tree in Bangkalan District

Table 7. Genetic distance of ayam ketawa in Bangkalan District

BD01 BS03 BD02 BS04 BS02 BS01 AD02 AS05 AS01 AS04 AD04 AS03 AD03 AD01 CS01 CS02 CD02 CD01 CD03 AS02

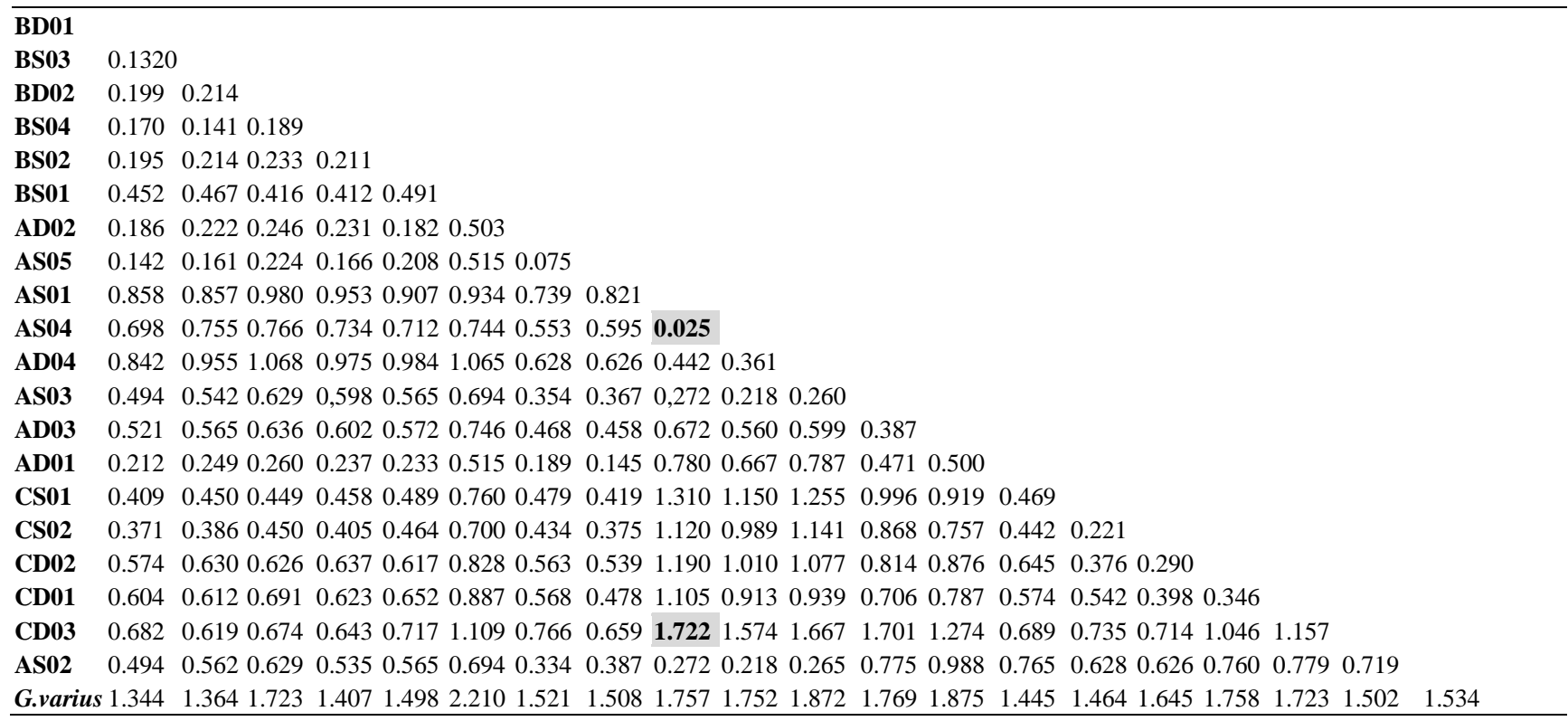

\section{REFERENCES}

Abinawanto A, Efendi PS. 2017. Biodiversity of the Gaga chicken from Pinrang, South Sulawesi, Indonesia based on the bioacoustic analysis and morphometric study. Biodiversitas 18: 1618-1623. DOI: 10.13057/biodiv/d180440.
Andrianto L, Baa LO, Rusdin M. 2015. Qualitative and quantitative characteristics of Gaga chicken from Kendari. Sci Technol J Anim Husb 1(4): 25-35. [Indonesian]

Arraushany A. 2017. Ayam Gaok the White gold of Madura Island, ready to be excavated. Technical Implementation Unit Animal Breeding and Animal Health Laboratory, Madura. East Java Provincial Animal Husbandry Office, Surabaya. [Indonesian] 
Bondoc OL, Santiago RC. 2012. The use of DNA barcodes in the evolutionary analysis of domestic breeds and strains of chicken (Gallus gallus domesticus ) in the Philippines. Philip Agric Sci 95(4): 358-369.

Bondoc OL. 2013. DNA barcoding of red jungle fowls (Gallus gallus philippensis Hatchisuka) from different mountain areas in Philippines. J Environ Sci Manag 16 (1): 1-10.

Bookstein FL. 1982. Foundation of morphometrics. Ann Rev Ecol Sys 13: 451-470. DOI: 10.1146/annurev.es.13.110182.002315.

Bugiwati SRA, Ashari F. 2013. Crowing sound analysis of Gaga chicken from South Sulawesi Indonesia. Intl J Plant Anim Environ Sci 3(2): 163-168.

Cooper MA, Washburn KW. 1998. The relationship of body temperature to weight gain, feed consumption and feed utilization in broiler under heat stress. Poult Sci 77: 237-242. DOI: 10.1093/ps/77.2.237.

Effendi PS. 2017. Diversity of Ayam Ketawa (Gallus gallus domesticus) Linneaus 1758 Based on Bioacoustic, Morphometric, and DNA Barcoding. [Thesis]. Universitas Indonesia, Depok. [Indonesian]

Effendi PS, Abinawanto. 2015. Biodiversity of the Gaga chicken (Ayam Ketawa) from Sidendreng-Rappang based on the bioacoustic analysis and the morphometric study. In: Mart $\mathrm{T}$, Triyono $\mathrm{D}$ (eds). International Symposium on Current Progress in Mathematics and Sciences, ISCPMS; Proceedings of the 1st International Symposium on Current Progress in Mathematics and Sciences. Depok, Indonesia, 3 November 2015. DOI: 10.1063/1.4946974.

Gao YS, Yun-Jare T, Xiu-Jun T, Jun-Xiang L, Xiao-Yan Z. 2011. Studies on the DNA barcoding of two newly discovered chickens by mt DNA COI gene. J Anim Vet Adv 10(13): 1711-1713. DOI: 10.3923/javaa.2011.1711.1713

Gunawan, Sihombing DTH. 2004. Effect of high environment on physiological conditions and productivity of native chickens. Wartazoa 14 (1): 31-39.

Hartl D. 2000. A primer of population genetics. $3^{\text {rd }}$ ed. Sinauer Associates, Inc, Sunderland, MA.

Hebert PDN, Stoeckle MY, Zemlak TS, Francis CM. 2004. Identification of birds through DNA barcodes. PLoS Biol 10: 1657-1663. DOI: 10.1371/journal.pbio.0020312.

Hillis DM. 2003. Molecules versus morphology in systematics. Ann Rev Ecol Sys 18(1): 23-42. DOI: 10.1146/annurev.es.18.110187.000323.

Hutt FB. 1949. Genetics of the Fowl. McGraw-Hill Book, New York.

Junaedi. 2012. Bioacoustic Characteristics of Gag Chicken in Sidrap District, South Sulawesi. [Thesis]. Universitas Hasanudin, Makassar. [Indonesian]

Klinck H, Mellinger D. 2010. Animal bioacoustics. www.animalbioacoustic.org. Accessed November 29, 2017.
Kumar S, Tamara K, Nei M. 2004. Mega 3: Integrated software for molecular evolutionary genetics analysis and sequence alignment. Brief Bioinformatics 5: 150-163. DOI: 10.1093/bib/5.2.150.

Mansjoer SS. 1985. Assessment of the Characteristics of the Production of Native Chickens and their Crosses with Rhode Island Red. [Dissertation]. Bogor Agricultural University, Bogor. [Indonesian]

Marler P, Doupe AJ. 2000. Singing in brain. Proc Natl Acad Sci USA 97 (7): 2965-2967. DOI: 10.1073/pnas.97.7.2965.

Maryono. 2012. Reaping Profit from the Ayam Ketawa Breeding. Kanisius, Yogyakarta. [Indonesian]

Mathur PK. 2003. Genotype-environment Interactions: Problems Associated with Selection for Increased Production. CABI Publishing, London.

Nei M, Kumar S. 2000. Molecular Evolution and Phylogenetics. Oxford University Press, New York.

Noerjanto E. 2007. Heat Stress Chickens, Stress Breeders. Trubus, Jakarta. [Indonesian]

Rachma SH, Haradab H, Dagonga MIA, Rahima L, Prahestia KI. 2013. Study of body dimension of Gaga' chicken, germ plasm of local chicken from South Sulawesi, Indonesia. Intl J Plant Anim Environ Sci 3(4): 204-209.

Rangkuti NA, Hamdan, Daulay AH. 2016. Identification of morphometrics and genetic distance of Kampung chickens in South Labuhanbatu. J Integrated Anim Husb 3 (1): 96-119.

Rukmana RH. 2003. Local Chickens: Intensification and Development Tips. Kanisius, Yogyakarta. [Indonesian]

Rusdin M, Nafiu LO, Saili T, Aku AS. 2011. The phenotypic characteristics of the qualitative traits of Tolaki chickens in Konawe District, Southeast Sulawesi. Agriplus Sci Mag 21 (3): 248-256.

Rusfidra. 2006. Bioacoustic Study on Chicken Bacengkok, Local Chicken Singer, West Sumatra. Universitas Andalas, Padang. [Indonesian]

Sheskin DJ. 2011. Handbook of Parametric and Nonparametric Statistical Procedures, $5^{\text {th }}$ ed. Chapman and Hall/CRC, Boca Raton, FL.

Sopia I, Yuwanto A. 2016. The winner contest laughs. http://jabar.tribunenews.com/2016/02/25/juara-kontes-ayam-ketawa. Accessed December 17, 2017. [Indonesian]

Tamura K, Peterson D, Peterson N, Stecher G, Nei M, Kumar S. 2011. Mega 5: Molecular evolutionary genetics analysis using Maximum Likelihood, Evolutionary Distance and Maximum Parsimony Methods. Mol Biol Evol 28: 2731-2739. DOI: 10.1093/molbev/msr121.

Zein MSA, Prawiradilaga DM. 2013. DNA Barcode Indonesian fauna. Kencana Prenadamedia Group, Jakarta. [Indonesian] 